\title{
Optimization of the Effect of Cutting Parameters on the Cutting Force in the Gradual Turning Process by Taguchi Method
}

\section{Oğur İYNEN ${ }^{1}$, Abidin ŞAHINOĞLU², Mustafa ÖZDEMIR ${ }^{3 *}$, Volkan YILMAZ ${ }^{4}$}

\begin{abstract}
In this experimental study, AISI 4140 steel was subjected to machining experiments on the CNC lathe. The effect of cutting forces (radial force (Fx), tangential force (Fy) and feed force (Fz)) depending on the cutting parameters were investigated experimentally. As cutting parameters, three different cutting speeds (V) (100 m min $\mathrm{m}^{-1} 140 \mathrm{~m} \mathrm{~min}^{-1}$ and $\left.180 \mathrm{~m} \mathrm{~min}^{-1}\right)$, feed rates (f) $\left(0.08 \mathrm{~mm} \mathrm{rev}^{-1}\right.$, $0.12 \mathrm{~mm} \mathrm{rev}^{-1}$ and $\left.0.16 \mathrm{~mm} \mathrm{rev}^{-1}\right)$ and cutting depths (a) $(0.5 \mathrm{~mm}, 0.9 \mathrm{~mm}$ and $1.3 \mathrm{~mm})$ were preferred. The experimental design was made according to the Taguchi L9 vertical array. The effects of cutting parameters on cutting forces and contribution rates were analyzed by analysis of variance (ANOVA). The effect levels of cutting parameters on cutting forces were determined using the $\mathrm{S} / \mathrm{N}$ ratio. Optimum cutting parameters are defined. After ANOVA analysis, it was determined that the feed rate was effective on the radial force and tangential force, while the depth of cut was effective on the feed force. According to the verification experiments, it was seen that the optimization was successfully applied.
\end{abstract}

Keywords: AISI 4140, Taguchi, cutting forces, machinability

\footnotetext{
${ }^{1}$ Oğur IYYNEN (Orcid ID: 0000-0003-1096-1836), Bozok University, Faculty of Engineering, Mechanical Engineering, Yozgat, Turkey E mail: ogur.iynen@bozok.edu.tr

${ }^{2}$ Abidin ŞAHINOĞLU (Orcid ID: 0000-0003-0040-442X), Department of Mechanical and Metal Technology, Çankırı Karatekin University, Çankırı, Turkey, E mail: abidinsahinoglu@gmail.com

${ }^{3}$ Mustafa ÖZDEMIR (Orcid ID: 0000-0002-7340-0940), Department of Machine and Metal Technology, Vocational School of Technical Sciences, Yozgat Bozok University, Yozgat, Turkey, E mail: mustafa.ozdemir@ bozok.edu.tr

${ }^{4}$ Volkan YILMAZ (Orcid ID: 0000-0002-8937-6527), Gazi University, Faculty of Technology, Manufacturing Engineering, Ankara, Turkey E mail: volkan@gazi.edu.tr
}

*Sorumlu Yazar/Corresponding Author: Mustafa ÖZDEMİR, e-mail: mustafa.ozdemir@bozok.edu.tr 


\section{INTRODUCTION}

AISI 4140 steel is one of the most commercially used cast steels. This material has approximately $10 \%$ usage in the machining industry. Also, this steel is a chrome-molybdenum steel, which is a low alloy steel. This material is also called medium carbon steel, alloy steel, low alloy structural steel and forged quality steel. AISI 4140 steels; Crankshaft, axle shaft, sleeve, automobile and aircraft construction, gear and wheel construction, machine tool, bolts, nuts etc. it has widespread use in parts (Demir, 2004; Höke et al., 2014, Kesti, 2009, Karayel and Nalbant, 2014). When the literature studies are examined, it is revealed that many studies have been carried out on stainless steels. Neşeli et al. turned AISI 4140 steel using carbide inserts under dry cutting conditions. According to the results of the analysis, it was seen that the a was the most effective parameter on all cutting force components (Neşeli et al., 2012). In the experimental study conducted by Özel et al., The effect of $\mathrm{V}, \mathrm{f}$, tool nose radius and workpiece hardness on surface roughness and cutting force were investigated experimentally in AISI H13 steel finishing turning (Özel et al., 2005). Panzera et al. investigated the effect of cutting parameters (V, f and a) of AISI 4340 steel on dry turning with coated carbide insert. In addition, the effects of cutting parameters on cutting force were investigated using ANOVA analysis results (Panzera et al., 2012). Jayant and Kumar used hardened steel AISI 4140 in their experimental study. The most appropriate cutting parameters were determined in the data obtained by using ANOVA and Taguchi Method (Jayant and Kumar, 2008). Yallese et al. have defined statistical models of cutting forces in machining AISI H11 hot work tool steel (50 HRC) material in dry cutting conditions. They created mathematical models with multiple linear regression and Response Surface Methodology (RSM) and determined the most effective cutting parameters on cutting forces (Aouici et al., 2010). Suresh et al. investigated the effect of cutting parameters (V, f, a and cutting time) on cutting forces, tool wear and surface roughness using the RSM method in turning of AISI 4340 hardened steel (Suresh et al., 2012). Abou-El-Hosseinb et al. conducted an experimental study to estimate the forces that occurred during the machining of AISI P20 tool steel. They evaluated the effects of four input parameters on the cutting force with RSM (Hosseinb et al., 2007). Aouici et al. experimentally examined the effect of $\mathrm{V}, \mathrm{f}$, a and workpiece hardness on surface roughness and cutting force components in hard turning operations. The mathematical model of the cutting force and surface roughness components has been developed using RSM (Aouici et al., 2012). Statistical analysis of surface roughness and cutting forces were carried out by RSM in hard turning of AISI 52100 bearing steel by Bouacha et al. The effect of cutting parameters on cutting forces and surface roughness was analyzed by ANOVA (Bouacha et al., 2010). An experimental study on the impact of cutting parameters $(\mathrm{V}, \mathrm{f}$ and a) on hard turning of MDN250 steel on cutting forces and surface roughness has been conducted by Lalwani et al. (Lalwani et al., 2008). Rao et al. examined the effects of cutting parameters ( $\mathrm{V}, \mathrm{f}$ and a) on cutting force and surface roughness when machining AISI 1050 steel material with ceramic coated tools. In the design of the experiment, he used Taguchi L27 and ANOVA analysis. According to the experimental results obtained, the $\mathrm{f}$ has been shown to affect both the cutting force and the surface roughness value (Rao et al., 2013). In this experimental study, the effect of $\mathrm{V}$, f and a parameters on AISI 4140 material on cutting forces were analyzed using the Taguchi method. The studies on AISI 4140 in the literature are especially finishing turning studies. No work on the machinability of this material with TCMT 16T304 NN LT 1000 cutting tool at high feed and depths of cut is available. In addition, in the AISI 4140 material, a large part of the sawdust is used for rough turning. However, there are few studies on cutting parameters and insert selection in the rough 
turning of this material. This experimental study was carried out to overcome these shortcomings in the literature.

\section{MATERIALS AND METHODS}

\section{Materials}

In this experimental study, the effect of three different $\mathrm{V}\left(100 \mathrm{~m} \mathrm{~min}^{-1}, 140 \mathrm{~m} \mathrm{~min}^{-1}\right.$ and $180 \mathrm{~m}$ $\left.\min ^{-1}\right)$, three different $\mathrm{f}\left(0.08 \mathrm{~mm} \mathrm{rev}^{-1}, 0.12 \mathrm{~mm} \mathrm{rev}^{-1}\right.$ and $\left.0.16 \mathrm{~mm} \mathrm{rev}^{-1}\right)$ and three different a $(0.5$ $\mathrm{mm}, 0.9 \mathrm{~mm}$ ve $1.3 \mathrm{~mm}$ ) on cutting forces (Fx, Fy and Fz) in the CNC turning machine of AISI 4140 steel was investigated. The chemical composition of the material used in the experimental study is shown in Table 1. It is of great importance to determine how much cutting parameters have an impact on which cutting force on the lathe. Because the cutting force on each axis causes a different wear mechanism. Also, the cutting force on each axis has a different effect on the workpiece. Therefore, it is necessary to measure the cutting forces by keeping them separate from each other. Therefore, in studies in the literature, similarly, three different cutting forces are measured in turning experiments. It is possible to calculate the total cutting forces. However, the calculation of these forces separately gives more detailed information about the manufacturing process.

Table 1. Chemical composition of AISI 4140 steel used in the experiments.

\begin{tabular}{lc}
\hline Constituent & Percentage present (\%) \\
\hline $\mathrm{C}$ & 0.41 \\
$\mathrm{Mn}$ & 0.83 \\
$\mathrm{Si}$ & 0.21 \\
$\mathrm{Cr}$ & 0.9 \\
$\mathrm{~S}$ & 0.026 \\
$\mathrm{P}$ & 0.029 \\
$\mathrm{Mo}$ & 0.18 \\
\hline
\end{tabular}

\section{Experimental procedure}

The experimental study was done on GOODWAY GS-260Y (15 kW motor power) model CNC lathe. In turning experiments, TTJNL 2525 M16 type tool holder and TCMT 16T304 NN LT 1000 cutting tools produced by LAMINA Technology company were used. The material used in the experiments is $80 \mathrm{~mm}$ in diameter and $160 \mathrm{~mm}$ in length. For each experiment, a $15 \mathrm{~mm}$ material was removed on the workpiece. Dry cutting conditions were preferred in the machining test. Figure 1 shows the experimental setup, where the experimental work is done. The cutting force measurements were measured with the Swiss-made KISTLER TYPE 9129AA model dynamometer connected to the CNC machine tool and KISTLER TYPE 5070 amplifier.

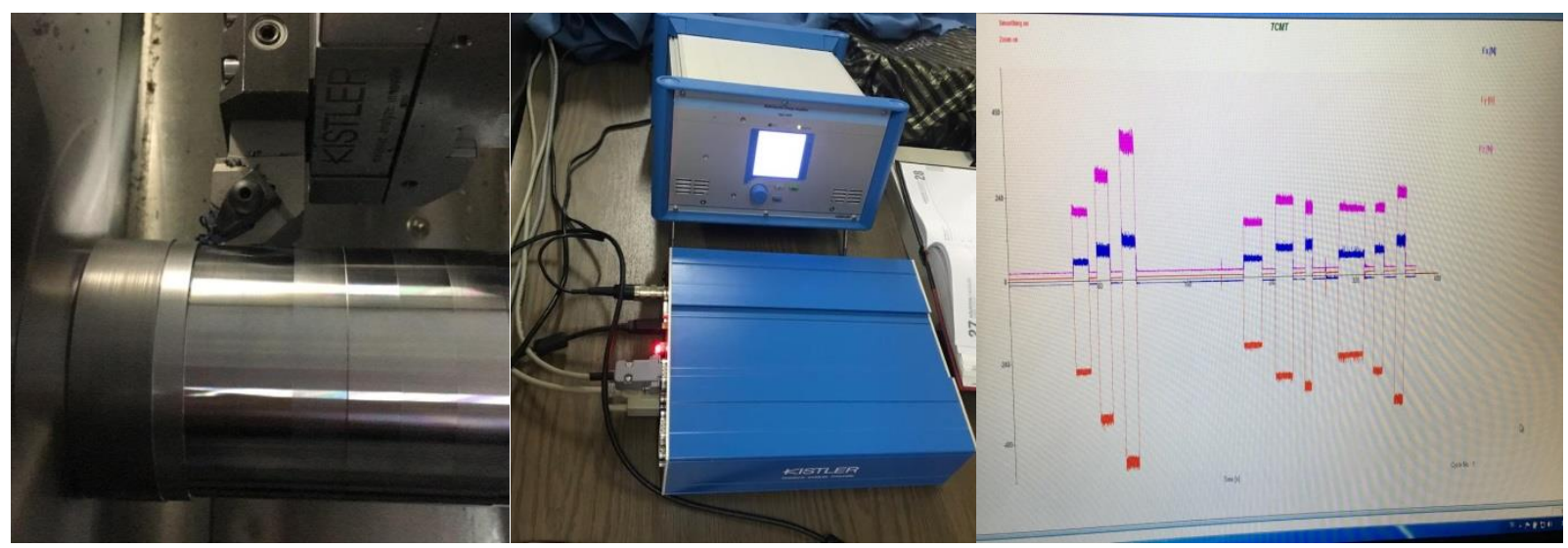

Figure 1. Experimental setup and cutting force measuring device 
Taguchi experiment design method is an experiment design method that minimizes the number of experiments that makes experimental studies shorter and easier. The Taguchi method is an experimental design method developed by Dr. Genichi Taguchi. Due to its benefits, this method has been widely used in the European and American industry after 1980s.Thanks to this method, it can be done with fewer experiments than the full factorial method, which is the optimization of long and expensive experiments. It is a method that can determine the effectiveness of the parameters in experimental studies, as well as reducing the experiment time and reducing the cost of the experiment. While preparing the experimental work plan, the parameters to be used in the experiments and their levels are determined. Then, the system is created by selecting the orthogonal arrays suitable for their degrees of freedom. In the interpretation of the experimental studies, it is converted to the performance characteristic known as S/N (signal / noise) ratio. The most commonly used performance characteristics are the smallest (the smallest, the best), the biggest best (The biggest, the best) and the nominal best (Nominal best). In this study, in determining $\mathrm{S} / \mathrm{N}$ values, since the cutting force values are desired to be the smallest, the formula corresponding to the "smallest best" principle given in Equation 1 is used (Ross, 1988; Gür et al., 2019; Savaş et al., 2016; Özdemir, 2019).

$$
S / N=-10 \cdot \log \left(\frac{1}{n} \cdot \sum_{i=1}^{n} Y_{i}^{2}\right)
$$

In the study, three different $\mathrm{V}\left(100 \mathrm{~m} \mathrm{~min}^{-1}, 140 \mathrm{~m} \mathrm{~min}^{-1}\right.$ ve $\left.180 \mathrm{~m} \mathrm{~min}^{-1}\right)$, three different $\mathrm{f}(0.08$ $\mathrm{mm} \mathrm{rev}{ }^{-1}, 0.12 \mathrm{~mm} \mathrm{rev}^{-1}$ ve $\left.0.16 \mathrm{~mm} \mathrm{rev}^{-1}\right)$ and three different depths of cut $(0.5 \mathrm{~mm}, 0.9 \mathrm{~mm}$ ve 1.3 $\mathrm{mm})$ were taken as cutting parameters. While $27(3 \times 3 \times 3)$ experiments should be done with the classical method, 9 experiments were designed by using Taguchi L9 vertical array. Each experiment was repeated 3 times and the arithmetic mean of the values was taken (Table 2).

In the experimental study, 3 different cutting speeds, 3 different feed rates and 3 different depths of cut were preferred. Therefore, 27 different experiments are required in full factorial experimental design. Taguchi L9 experiment design was preferred to reduce the number of experiments, reduce the time of the experiment and reduce the costs of the experiment. L9 experiment design was decided by examining the literature studies. Minitab 16.0 software was used in the experimental design and statistical analysis according to the Taguchi method.

Table 2. Control factors and their levels

\begin{tabular}{cccccc}
\hline Factors & Symbol & Unit & Level 1 & Level 2 & Level 3 \\
\hline Cutting speed & $\mathrm{V}$ & $\mathrm{m} \mathrm{min}^{-1}$ & 100 & 140 & 180 \\
Feed rate & $\mathrm{f}$ & $\mathrm{mm} \mathrm{rev}^{-1}$ & 0.08 & 0.12 & 0.16 \\
Depth of cut & $\mathrm{a}$ & $\mathrm{mm}$ & 0.5 & 0.9 & 1.3 \\
\hline
\end{tabular}

\section{RESULTS AND DISCUSSION}

Table 3 shows the cutting force values obtained from the experiments performed according to the Taguchi L9 vertical array and the $\mathrm{S} / \mathrm{N}$ ratios of these values. Minitab 16.0 statistical software program was used to analyze the effects of cutting parameters on cutting forces. $\mathrm{S} / \mathrm{N}$ ratio and variance analysis (ANOVA) were created at $95 \%$ confidence level. The level with the highest value in $\mathrm{S} / \mathrm{N}$ ratio for each control factor means the best level for that factor. The lowest forces $(53.95 \mathrm{~N}, 207.5 \mathrm{~N}$ and $162 \mathrm{~N}$ ) corresponding to the values $(\mathrm{S} / \mathrm{N}=-34.6398, \mathrm{~S} / \mathrm{N}=-46.3404$ and $\mathrm{S} / \mathrm{N}=-44.1903)$ for $\mathrm{Fx}, \mathrm{Fy}$, Fz respectively has been identified. The cutting parameters giving the lowest cutting force value on Fx; It was observed that the $\mathrm{V}$ of $180 \mathrm{~m} \mathrm{~min}^{-1}$, the $\mathrm{f}$ of $0.08 \mathrm{~mm} \mathrm{rev}^{-1}$ and the $0.9 \mathrm{~mm}$ a (V3-f1-a3). For Fy 
and $\mathrm{Fz}, 140 \mathrm{~m} \mathrm{~min}^{-1} \mathrm{~V}, 0.08 \mathrm{~mm} \mathrm{rev}^{-1} \mathrm{f}$ and $0.9 \mathrm{~mm}$ a (V2-f1-a2) are the cutting parameters corresponding to the lowest forces.

Table 3. L9 orthogonal array, experimental results and their $\mathrm{S} / \mathrm{N}$ ratios for cutting forces

\begin{tabular}{cccccccccc}
\hline \multirow{2}{*}{$\begin{array}{c}\text { Number of } \\
\text { Experiments }\end{array}$} & \multicolumn{3}{c}{$\begin{array}{c}\text { Machining } \\
\text { Parameters }\end{array}$} & \multicolumn{3}{c|}{ Measured cutting forces } & \multicolumn{3}{c}{ S/N Ratios } \\
\cline { 2 - 10 } & $\mathbf{V}$ & $\mathbf{f}$ & $\mathbf{a}$ & $\mathbf{F x}(\mathbf{N})$ & $\mathbf{F y}(\mathbf{N})$ & $\mathbf{F z}(\mathbf{N})$ & $\mathbf{F x}(\mathbf{d B})$ & $\mathbf{F y}(\mathbf{d B})$ & $\mathbf{F z}(\mathbf{d B})$ \\
\hline $\mathbf{1}$ & 100 & 0.08 & 0.5 & 61.92 & 248.7 & 202.1 & -35.8366 & -47.9135 & -46.1113 \\
$\mathbf{2}$ & 100 & 0.12 & 0.9 & 86.18 & 306.1 & 226.2 & -38.7081 & -49.7173 & -47.0899 \\
$\mathbf{3}$ & 100 & 0.16 & 1.3 & 114.10 & 549.9 & 391.5 & -41.1457 & -54.8057 & -51.8546 \\
$\mathbf{4}$ & 140 & 0.08 & 0.9 & 55.91 & 207.5 & 162.0 & -34.9498 & $\mathbf{- 4 6 . 3 4 0 4}$ & $\mathbf{- 4 4 . 1 9 0 3}$ \\
$\mathbf{5}$ & 140 & 0.12 & 1.3 & 86.25 & 415.4 & 300.7 & -38.7152 & -52.3693 & -49.5627 \\
$\mathbf{6}$ & 140 & 0.16 & 0.5 & 101.40 & 392.5 & 248.7 & -40.1208 & -51.8768 & -47.9135 \\
$\mathbf{7}$ & 180 & 0.08 & 1.3 & 53.95 & 270.7 & 198.2 & $\mathbf{- 3 4 . 6 3 9 8}$ & -48.6498 & -45.9421 \\
$\mathbf{8}$ & 180 & 0.12 & 0.5 & 76.74 & 300.5 & 202.9 & -37.7004 & -49.5569 & -46.1456 \\
$\mathbf{9}$ & 180 & 0.16 & 0.9 & 94.46 & 340.7 & 206.1 & -39.5050 & -50.6474 & -46.2816 \\
\hline
\end{tabular}

The S/N response table is used to analyze the effect of each control factor on cutting forces. In Figure 2-Figure 4, as a result of the analysis obtained, $\mathrm{S} / \mathrm{N}$ effect levels of cutting parameters to cutting forces are given. It shows the optimum levels of control factors for optimum cutting force values. The best level for the control factors is shown according to the largest $\mathrm{S} / \mathrm{N}$ ratio in all levels of that control factor. According to this analysis, the levels and $\mathrm{S} / \mathrm{N}$ ratios of the cutting parameters that give the optimum Fx, Fy and Fz values are factor V (Level 3; $\mathrm{S} / \mathrm{N}=-37.28 ;-49.62 ;-46.12$ ), factor $\mathrm{f}$ (Level 1; $\mathrm{S} / \mathrm{N}=-35.14 ;-47.63 ;-45.41)$ and factor a (Level $2 ; \mathrm{S} / \mathrm{N}=-37.72 ;-48.90 ;-45.85)$ determined as. In other words, as seen in Figure 2, the optimum Fx value was obtained at a V of $180 \mathrm{~m} \mathrm{~min}^{-1}$ (V3), f of $0.08 \mathrm{~mm} \mathrm{rev}^{-1}$ (f1) and a (a2) of $0.9 \mathrm{~mm}$. While the most effective control factors on Fx in order of importance are the $\mathrm{f}, \mathrm{V}$ and a, while the most effective control factors on Fy and Fz are determined as the f, a and V (Figure 3 and Figure 4).

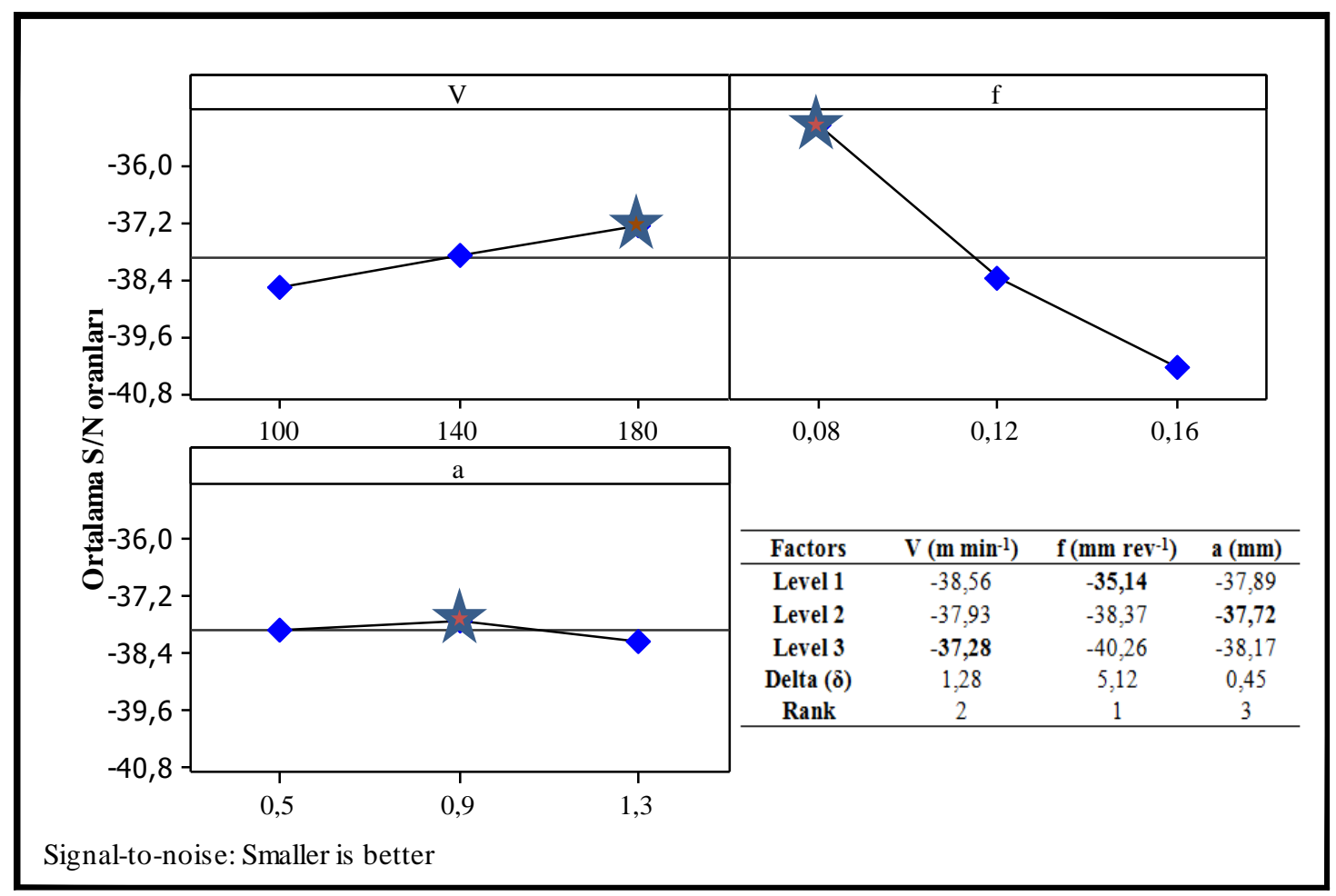

Figure 2. Main Impact Graph for S/N Ratios, (Fx) 


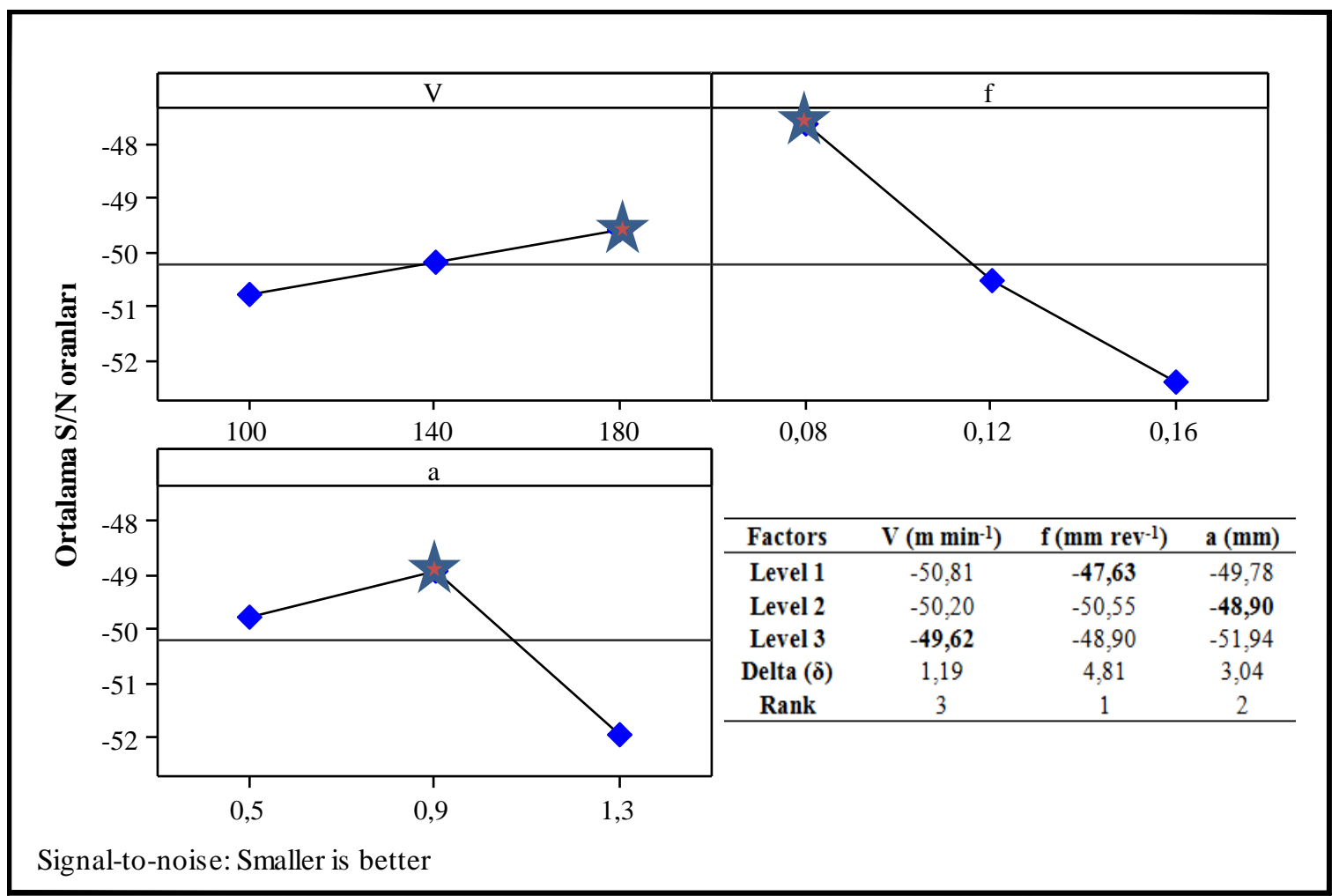

Figure 3. Main Impact Graph for S/N Ratios, (Fy)

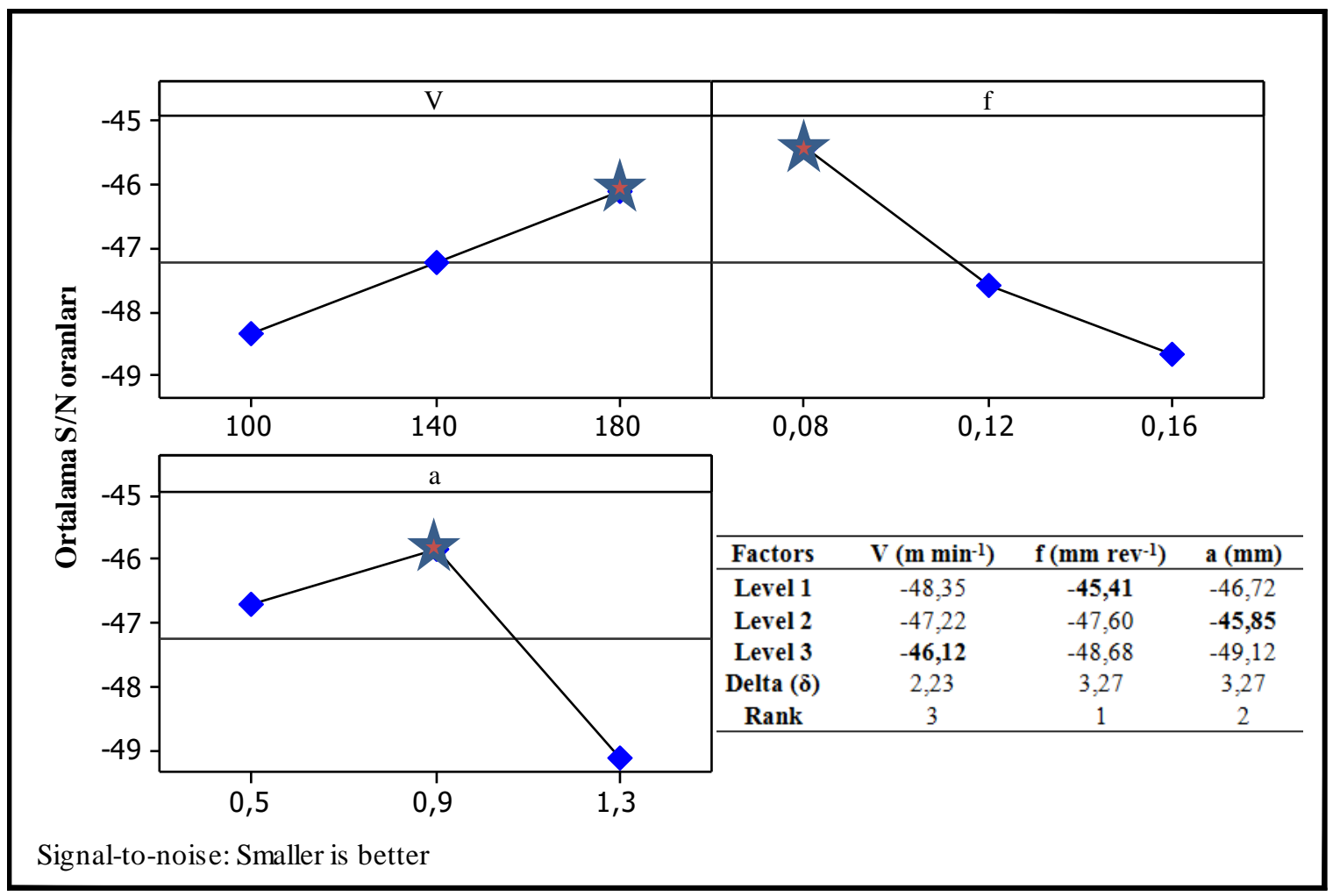

Figure 4. Main Impact Graph for S/N Ratios, $(\mathrm{Fz})$

The surface graph in Figure 5 shows the effects of cutting parameters on Fx, Fy and Fz. As seen in the graphs in Figures 5a, 5b, 5d, 5e, 5g and 5h, the cutting force decreases with increasing V. The reason for the decrease in cutting force values due to the increase in $\mathrm{V}$ is the increase in temperature in the cutting zone with increasing V. Depending on the increasing temperature, thermal softening occurs and plastic deformation is easier to machining. Therefore, cutting forces are decreasing (Taşliyan et al., 
2007; Meddour et al., 2018; Özçatalbaş, 2002; Kurt and Şeker, 2005; Çakır, 1999; Akkurt, 2004). The amount of reduction in cutting force may differ depending on the material type, machining conditions and $\mathrm{V}$ range studied. As seen in Figures $5 \mathrm{c}, 5 \mathrm{f}$ and 51 , as the $\mathrm{f}$ increases, the cutting force values increase. It is observed that there is a direct proportional relationship between increasing $\mathrm{f}$ values and Fx, Fy, Fz. Depending on the $\mathrm{f}$ and the increase in a, the increase on Fx, Fy and Fz is an expected condition. In order to reduce the cutting forces, the $\mathrm{f}$ value must be reduced. Low a and low $\mathrm{f}$ values are preferred especially in finish turning operations. Thus, a better surface quality is obtained.
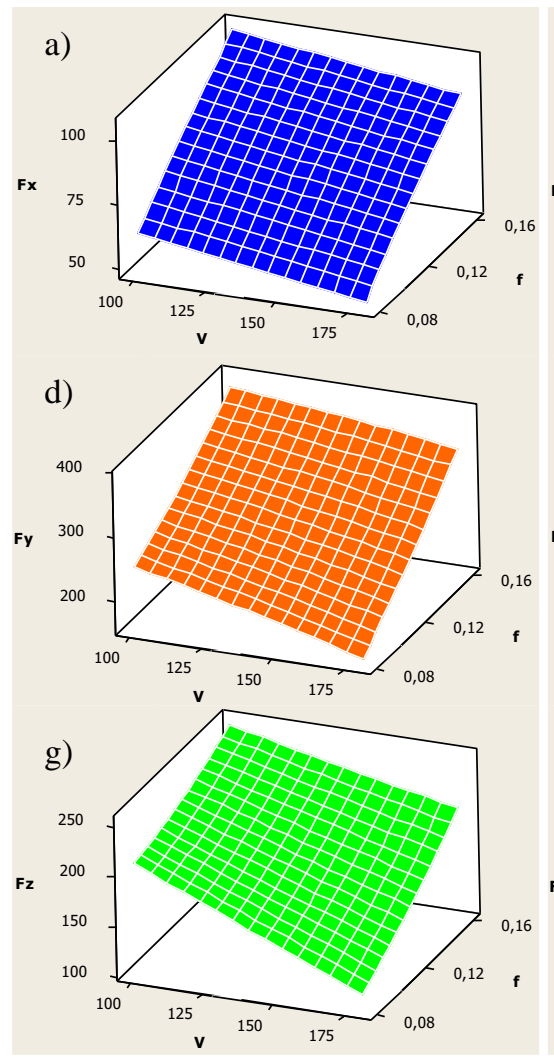
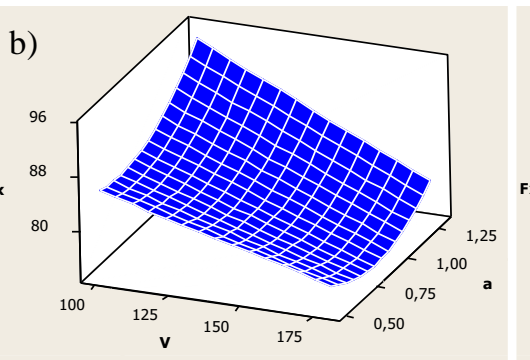

e)
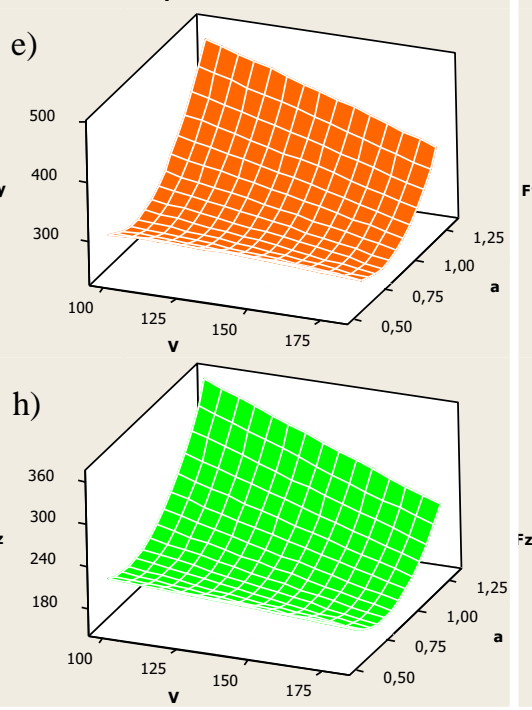

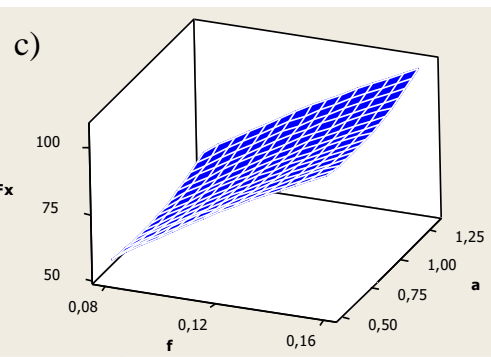

f)
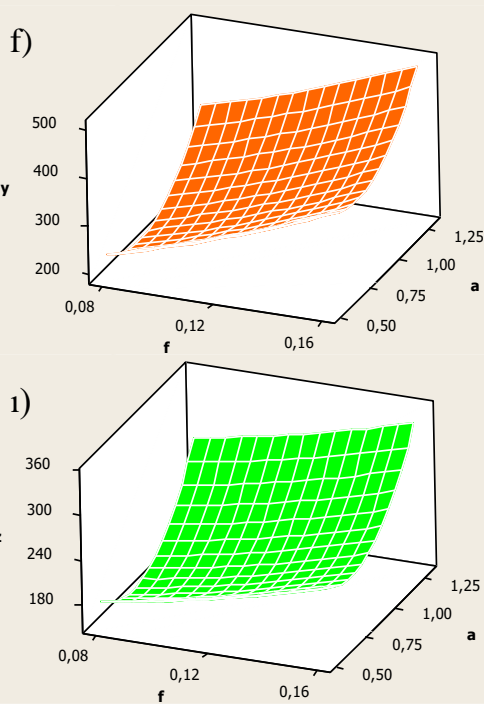

Figure 5. Effect of cutting parameters on Fx, Fy and Fz

Variance analysis (ANOVA) was performed to explain the effect amounts of cutting parameters used in the experimental design on cutting forces (Fx, Fy and Fz). The effect quantities of cutting parameters used in experimental design on cutting forces (Fx, Fy and Fz) were analyzed with variance analysis (ANOVA). The ANOVA values obtained show the effect rate of factors $\mathrm{V}, \mathrm{f}$ and a on the cutting force. Table 4-Table 6 shows the ANOVA results performed in the $95 \%$ confidence interval of Fx, Fy and Fz. When Table 4a is examined, it is seen that the a is not effective on the cutting force in terms of $\mathrm{p}<0.05$ significance value. The $\mathrm{f}$ and the $\mathrm{V}$ are significant in the $95 \%$ confidence interval. As can be seen in Table 4a, the effect of the $\mathrm{f}$ on the Fx force is $93.42 \%$ and the effect of the V is $5.73 \%$. So the most effective factor on Fx is the $\mathrm{f}$, followed by V. When Table $4 \mathrm{~b}$ is examined, it is seen that $\mathrm{V}, \mathrm{f}$ and a are significant in terms of $\mathrm{p}<0.05$ significance value. When the contribution rates of cutting parameters on Fy are examined, it is seen that the most effect is the f with $67.57 \%$, this is the a with $28.17 \%$, and finally the $\mathrm{V}$ with the effect rate of $4.11 \%$. According to Table $4 \mathrm{c}$, when the factors on the Fy value are listed according to the degree of effect, it is seen that there is the $\mathrm{f}$, a and $\mathrm{V}$. The effect rates of cutting parameters on Fz force are; $\mathrm{a}$ is $41.32 \%, \mathrm{f}$ is $40.04 \%$ and $\mathrm{V}$ is $17.94 \%$. 
Table 4. ANOVA Results for Taguchi L9 Experiment Design

\begin{tabular}{|c|c|c|c|c|c|c|c|}
\hline \multicolumn{8}{|c|}{ a- Anova Results for Fx } \\
\hline Factor & DF & Seq SS & Adj SS & Adj MS & $\mathbf{F}$ & $\mathbf{P}$ & $\%$ contr. \\
\hline $\mathbf{V}$ & 2 & 2.4644 & 2.4644 & 1.2322 & 42.58 & 0.023 & 5.73 \\
\hline $\mathbf{f}$ & 2 & 40.1570 & 40.1570 & 20.0785 & 693.83 & 0.001 & 93.42 \\
\hline $\mathbf{a}$ & 2 & 0.3050 & 0.3050 & 0.1525 & 5.27 & 0.159 & 0.71 \\
\hline Error & 2 & 0.0579 & 0.0579 & 0.0289 & & & 0.13 \\
\hline Total & 8 & 42.9843 & & & & & 100.00 \\
\hline \multicolumn{8}{|c|}{$\mathrm{S}=0.1701 \mathrm{R}^{2}=\% 99.9 \mathrm{R}^{2}($ pred $)=\% 99.5$} \\
\hline \multicolumn{8}{|c|}{ b- Anova Results for Fy } \\
\hline $\mathbf{V}$ & 2 & 2.1397 & 2.1397 & 1.0698 & 26.25 & 0.037 & 4.11 \\
\hline $\mathbf{f}$ & 2 & 35.2042 & 35.2042 & 17.6021 & 431.84 & 0.002 & 67.57 \\
\hline $\mathbf{a}$ & 2 & 14.6787 & 14.6787 & 7.3394 & 180.06 & 0.006 & 28.17 \\
\hline Error & 2 & 0.0815 & 0.0815 & 0.0408 & & & 0.16 \\
\hline Total & 8 & 52.1041 & & & & & 100.00 \\
\hline \multicolumn{8}{|c|}{$\mathrm{S}=0.2019 \mathrm{R}^{2}=\% 99.8 \mathrm{R}^{2}($ pred $)=\% 99.4$} \\
\hline \multicolumn{8}{|c|}{ c- Anova Results for $\mathrm{Fz}$} \\
\hline V & 2 & 7.4521 & 7.4521 & 3.7261 & 25.54 & 0.038 & 17.94 \\
\hline $\mathbf{f}$ & 2 & 16.6324 & 16.6324 & 8.3162 & 57.01 & 0.017 & 40.04 \\
\hline $\mathbf{a}$ & 2 & 17.1645 & 17.1645 & 8.5822 & 58.83 & 0.017 & 41.32 \\
\hline Error & 2 & 0.2918 & 0.2918 & 0.1459 & & & 0.70 \\
\hline Total & 8 & 41.5407 & & & & & 100.00 \\
\hline $\mathrm{S}=0.3819$ & 9.3 & $1)=\% 97.2$ & & & & & \\
\hline
\end{tabular}

In the experiments performed after the design of the Taguchi L9 experiment, the effect of cutting parameters on the cutting force was analyzed. At the final stage of the Taguchi design, optimization experiments were carried out. In this experimental study, optimum cutting parameters were determined. Then, 3 optimization tests were carried out to ensure the accuracy of the experiments. In accordance with the standards of turning tests, the tests were repeated 3 times. After this optimization, $180 \mathrm{~m} \mathrm{~min}^{-1} \mathrm{~V}, 0.08 \mathrm{~mm} \mathrm{rev}^{-1} \mathrm{f}$ and $0.9 \mathrm{~mm}$ a factors are seen as the most suitable parameter for cutting forces. Verification experiments were carried out using parameter levels V3-f1-a2.As a result of the experiments, Fx value was reached with $96.7 \%$, Fy $97.5 \%$ and Fz with $96.9 \%$ estimated values.

Table 5. Optimization test results for cutting forces

\begin{tabular}{cccccccc}
\hline Factor & Level & \multicolumn{2}{c}{ Fx (N) } & \multicolumn{2}{c}{ Fy (N) } & \multicolumn{2}{c}{ Fz (N) } \\
\hline V3 & 180 & Prediction & Experimental & Prediction & Experimental & Prediction & Experimental \\
\cline { 3 - 8 } f1 & 0.08 & \multirow{2}{*}{48.74} & 50.37 & 157.26 & 161.16 & 112.73 & 109.25 \\
a2 & 0.9 & & & & & & \\
\hline
\end{tabular}

\section{CONCLUSION}

Findings obtained as a result of the experimental study examining the effect of AISI 4140 material on V, f and a parameters on cutting forces (Fx, Fy and Fz) are stated below. As a result of the experiments, it was observed that the lowest cutting force on Fx was $53.95 \mathrm{~N}$, the V of $180 \mathrm{~m} \mathrm{~min}^{-1}$, the $\mathrm{f}$ of $0.08 \mathrm{~mm} \mathrm{rev}{ }^{-1}$ and the a of $1.3 \mathrm{~mm}$. In Fy and Fz values, $140 \mathrm{~m} \mathrm{~min}^{-1} \mathrm{~V}, 0.08 \mathrm{~mm} \mathrm{rev}^{-1} \mathrm{f}$ and $0.9 \mathrm{~mm}$ a factors, respectively; It was observed that it corresponds to the force values of $207 \mathrm{~N}$ and $162 \mathrm{~N}$.

As the $\mathrm{V}$ increases, Fx, Fy and Fz are decreasing, Fx, Fy, Fz increase with increasing the $\mathrm{f}$ and a. It was observed that there is an inverse proportional relationship between the $\mathrm{V}$ and $\mathrm{f}$ on cutting forces. 
One of the most effective parameters on Fx and Fy is the f. The effect rate of the f on Fx and Fy, respectively; $93.42 \%$ and $67.57 \%$. On Fz, the a effect rate was found to be $41.32 \%$. The second effective parameters on Fx, Fy and Fz are 5.73\% V, 28.17\% a and 40.04\% f, respectively. The factors that have the least effect on cutting forces (Fx, Fy and Fz) and contribution rates were seen as $0.71 \%$ a, $4.11 \% \mathrm{f}$ and $17.94 \% \mathrm{~V}$.

Optimum cutting parameters according to $\mathrm{S} / \mathrm{N}$ ratios; $180 \mathrm{~m} \mathrm{~min}^{-1} \mathrm{~V}, 0.05 \mathrm{~mm} \mathrm{rev}^{-1} \mathrm{f}$ and 0.09 $\mathrm{mm}$ a (V3-f1-a2). As a result of the verification experiments, Fx, Fy and Fz values were estimated at $96.7 \%, 97.5 \%$ and $96.9 \%$ proximity rates, respectively.

\section{REFERENCES}

Abou-El-Hossein KA, Kadirgama K, Hamdi M, Benyounis KY, 2007. Prediction of cutting force in end-milling operation of modified AISI P20 tool steel, Journal of Materials Processing Technology 182:241-247.

Akkurt M, 2004. Talaş kaldırma yöntemleri ve Takım tezgâhları, Birsen Yayın Evi, Istanbul.

Aouici H,Yallese MA, Fnides B, Mabrouki T, 2010. Machinability investigation in hard turning of AISI H11 hotwork steel with CBN tool, Mechanika 86:71-77.

Aouici H, Yallese MA, Chaoui K, Mabrouki T, Rigal JF, 2012. Analysis of surface roughness and cutting force components in hard turning with CBN tool: prediction model and cutting conditions optimization, Meas. J. Int. Meas. Confed. 45:344-353.

Bouacha K, Yallese MA, Mabrouki T, Rigal JF, 2010. Statistical analysis of surface roughness and cutting forces using response surface methodology in hard turning of AISI 52100 bearing steel with CBN tool, Int. Journal of Refractory Metals \& Hard Materials 28:349-361.

Çakır C, 1999. Modern talaşlı imalatın esasları, Uludağ Üniversitesi Güçlendirme Vakfı Yayınları, Bursa 140: 1-110.

Demir B, 2004. Ç4140 çeliğinden çift-fazlı çelik üretilebilirliğinin incelenmesi. Teknoloji Dergisi, 7(1):121-127.

Gür AK, Taşkaya S, Özay Ç, 2019. Ramor 500 Çeliğinde Isıl İşlemin Mikroyapı, Mikrosertlik ve Abrasiv Aşınma Direncine Etkisinin Taguchi Metoduyla Değerlendirilmesi, BEÜ Fen Bilimleri Dergisi, 8(3): 1045-1056.

Höke G, Şahin İ, Çinici H, Fındık T, 2014. Kriyojenik işlemin SAE 4140 çeliğin mekanik özellikleri üzerine etkisi. Selçuk Teknik-Online Dergi, 13(2):25-37.

Jayant A, Kumar V, 2008. Prediction of surface roughness in CNC turning operation using taguchi design of experiments, Journal of the Institution of Engineers, Production Engineering Division 88:19-25.

Karayel B, Nalbant M, 2014. Effects of feedrate, cuttıng speed and cuttıng tools on average surface roughness, tool life and wear in turning of AISI 4140 material. Electronic Journal of Machine Technologies, 11:11-26.

Kesti E, (2009). Ç - 4140 Çeliğinin, Mikro Yapı Ve Mekanik Özelliklerine Su Verme Ortamının Etkilerinin Araştırılması. Yüksek Lisans Tezi, Selçuk Üniversitesi Fen Bilimleri Enstitüsü, Makine Mühendisliği Anabilim Dalı, Konya, 99s.

Kurt A, Seker U, 2005. The effect of chamfer angle of polycrystalline cubic boron nitride cutting tool on the cutting forces and the tool stresses in finishing hard turning of AISI 52100 steel, Materials and Design 26:351-356. 
Lalwani DI, Mehta NK, Jain PK, 2008. Experimental investigations of cutting parameters influence on cutting forces and surface roughness in finish hard turning of MDN250 steel, journal of materials processing technology 206:167-179.

Meddour I, Yallese MA, Bensouilah H, Khellaf A, Elbah M, 2018. Prediction of surface roughness and cutting forces using RSM, ANN, and NSGA-II in finish turning of AISI 4140 hardened steel with mixed ceramic tool. Int. J. Adv. Manuf. Technol. 97(5-8):1931-1949.

Neşeli S, Asıltürk İ, Yaldız S, Saglam H, 2012. Tornalama İşleminde Cevap Yüzey Metodu ile Kesme Kuvvetlerinin Kesme Parametrelerine Bağlı Olarak Modellenmesi. 3. Ulusal Talaşlı İmalat Sempozyumu, Ankara.

Özçatalbaş Y, 2002. The Effects of Tool Wear and Mechanıcal Propertıes of Workpiece Material on Surface Roughness and Cuttıng Forces, Journal of Polytechnic 4:47-52.

Özdemir M, 2019. Optimization with Taguchi Method of Influences on Surface Roughness of Cutting Parameters in CNC Turning Processing, Mechanika 25:397-405.

Özel T, Hsu TK, Zeren E, 2005. Effects of cutting edge geometry, workpiece hardness, feed rate and cutting speed on surface roughness and forces in finish turning of hardened AISI H13 steel, Int J Adv Manuf Technol 25:262-269.

Panzera TH, Souza PR, Rubio JCC, Abrao AM, Mansur TR, 2012. Development of a three-component dynamometer to measure turning force, The International Journal of Advanced Manufacturing Technology 62:913-922.

Rao, D. C. J., Rao, D. D. N. and Srihari, P. (2013). Influence of cutting parameters on on cutting force and surface finish in turning operation. International Conference On Design and Manufacturing 64:1405-1415.

Ross PJ, 1988. Taguchi Techniques for Quality Engineering, Mc-Graw-Hill, New York.

Savas V, Ozay C, Ballikaya H, 2016. Experimental investigation of cutting parameters in machining of 100Cr6 with tangential turn-milling method. Adv. Manuf., 4(1): 97-104.

Suresh R, Basavarajappa S, Gaitonde VN, Samuel GL, 2012. Machinability investigations on hardened AISI 4340 steel using coated carbide insert, Int. J. Refract. Metals Hard Mater. 33:75-86.

Taşliyan A, Acarer M, Şeker U, Gökkaya H, Demir B, 2007. Inconel 718 Süper Alaşımının İşlenmesinde Kesme Parametrelerinin Kesme Kuvveti Üzerindeki Etkisi. Gazi Üniversitesi Mühendislik-Mimarlık Fakültesi Dergisi 22(1):1-5. 